Int. J. Speleol. 11 (1981), pp. 15-20.

\title{
Genetic Population Structure in an Amphipod Species
}

\author{
J.L. Gooch* \\ and S.W. Golladay**
}

\begin{abstract}
SUMMARY
Genetic structure of a species should conform, in part, to environmental structure. Three polymorphic enzyme loci in the amphipod Gammarus minus Say are geographically differentiated in gene frequencies in the mid-Appalachian Mountains of the eastern United States, and genetic breaks usually coincide with topographical features and stream divides. Considering alleles as migrational markers, it is expected that heterozygosity would decrease upstream in isolated drainage basins, increase in the headwaters of adjacent but oppositely flowing streams in which gene exchange was occurring between genetically differentiated populations, and increase in sites near regional master streams. These genetic patterns were found to exist in an area near the Juniata River in central Pennsylvania.
\end{abstract}

\section{INTRODUCTION}

It is an article of faith among ecological geneticists that genetic patterns exist in natural populations, even if the "patterns" are stochastically varying gene frequencies that fit only theoretical models of random drift. A few examples of relatively clear-cut and environmentally-correlated genetic patterns are known in animals and plants (e.g., Johnson, 1971; Koehn, 1969; Schopf, 1973). More commonly geographical patterns are roughly delineated and their origins are speculative and perhaps multiple (e.g., Aspinwall, 1974; Cockley, et al., 1977; Gorman, et al., 1975).

Geographic-genetic patterns are likely to be sharpest in highly structured environments. There the prominent environmental grain should be maximally imposed on the geographical components of species genetic structure. Regional genetic patterns are distinct in Gammarus minus Say (Amphipoda) in springs and spring-fed streams of the mid-Appalachian Mountains of the eastern United States. We investigated three allozyme systems coded by polymorphic loci (malate dehydrogenase, $M d h-1$; phosphoglucose isomerase, Pgi1; peptidase, Pep-I) using electrophoretic techniques on cave and spring populations in karst areas of southeastern West Virginia (Gooch and Hetrick, 1979). Gene frequencies were found to be highly differentiated geographically, and genetic breaks usually coincided with surface topographic and subsur-

* Biology Department, Juniata College Huntingdon, PA 16652, U.S.A.

** Present address: Department of Biology, Virginia Polytechnic Institute and State University, Blacksburg, VA 24061, U.S.A. . 
face karstic divides. This study has recently been extended to include 175 populations over a four state area. A portion of this wider study is reported here, centering on an area of central Pennsylvania.

The study area lies in a typical segment of the folded Appalachians characterized by linear southwest-trending clastic ridges separated by shale and carbonate valleys. Peak abundances of Gammarus minus are in the carbonate valleys. The drainage forms a trellis pattern, with smaller streams occupying strike valleys and larger trunk streams flowing usually southeast across the geological structure and breaching the ridges through water gaps.

Amphipod populations have undergone marked differentiation in gene frequencies at any one or more of the three loci. No correlation has been detected, however, between the frequency of any allele and substrate composition, sediment size and texture, temperature, vegetation type, water hardness, or other variables (Gooch, unpublished data). Therefore alleles will be treated here solely as markers or tags of amphipod movements, which are undoubtedly channelized along surface streams in most cases. Phoresy on large animals, stream piracy, and especially subsurface movements in limestone areas are usually subordinate factors in migration.

\section{RESULTS AND DISCUSSION}

Figure 1 depicts patterns of genetic variability or heterozygosity hypothetically created by gene exchange among genetically differentiated populations. In Fig. 1A a small drainage basin is shown enclosed by clastic ridges on three sides. There is no water access into the basin except upstream from the trunk stream. Heterozygosity decreases upstream, reflecting the multiple founding episodes required to complete the colonization of the entire basin. The process is schematized in Fig. 1C. A hypothetical small population initially occupies a site near the stream mouth. A representative amphipod has the 3-locus genotype $a^{\prime} a b b c^{\prime} c$ and is thus heterozygous at two of three loci (67\% polymorphic). Subsequently a few individuals, or perhaps a single brooding female, colonize the central area of the basin and $a$ ' is not represented among the founders. Only the $c$ locus remains polymorphic (33\%). Finally the headwater reaches are colonized, but with the further chance loss of the $c$ allele. The headwater populations are now monomorphic for all three loci $(0 \%)$, and the pattern of diminishing heterozygosity upstream is completed.

In Fig. 1B heterozygosity is shown highest in headwaters of juxtaposed and oppositely-flowing drainages separated by a low divide. As in Fig. 1A, upstream populations become increasingly monomorphic and genetically differentiated. Here, however, the divide is an incomplete barrier to migration, and gene exchange occurs by one of the mechanisms not requiring continuity of surface drainage listed previously. Local gene exchange gives rise to a headwater zone of high heterozygosity.

A regional trunk stream with tributaries is shown in Fig. 1C. Heterozygosity is highest in populations nearest the master stream and declines in all directions. This is because: (1) the smallest number of colonizing episodes is 
required to initially populate the downstream habitable reaches of the tributaries, and (2) the trunk stream serves as the primary avenue of continuing gene exchange among established populations. Continuing gene exchange is probably intermittent and not extensive. We have never found permanent populations of G. minus in higher than third-order streams, although we have seined isolated individuals from large streams.

The heterozygosity patterns of Fig. 1 are singly exhibited in several places in the study area. We will describe a locality that exemplifies in mixed form all three patterns. Fig. 2 shows an approximately $1100 \mathrm{~km}^{2}$ area of central Pennsylvania. Two branches of the Juniata River flowing southeastward traverse the long, $350 \mathrm{~m}$ high ridge of Tussey Mountain through two water gaps and then unite to form the Juniata River proper. Pie sectors depict frequencies of the $b, f$ and $g$ alleles at the Mdh-l locus of populations in strike valleys paralleling the ridge on both sides. East of Tussey Mountain, 11 northern populations remote from the water gaps ( 3 shown and 8 additional) are virtually monomorphic for $f$, and 22 populations well south of the gaps ( 3 shown, 19 additional) are also fixed for $f$. Northwest of the ridge, in Nittany Valley, the $f$ allele is rare and $b$ and $g$ predominate. To the southwest all three alleles are in high frequency.

Clearly the Tussey Mountain barrier has permitted strong genetic differentiation to develop in the flanking valleys. The Nei index of genetic similarity (Nei, 1972) was determined for the three loci between five populations bordering Spruce Creek northwest of the ridge, and five near Shavers Creek and Standing Stone Creek northeast of the ridge. An index of 0 denotes no alleles in common and 1.0 complete genic identity. The mean Nei index of west versus east side populations is $0.37 \pm 0.02$ (indices are not normally distributed, so SE approximates confidence in mean). In contrast, the index among western populations is $0.90 \pm 0.03$ and among eastern $0.99 \pm 0.01$.

Near the two water gaps on the eastern or downstream side the pattern of regional differentiation breaks down. The 16 populations nearest the gap are genetically mixed; the $b$ and $g$ alleles, elsewhere confined west of Tussey Mountain, exist in high frequency along with $f$. Fig. 2 shows that the zone of mixing extends about $20 \mathrm{~km}$ to the south and at least $12 \mathrm{~km}$ north and east. There is less evidence for gene exchange westward, except for an appreciable frequency of $f$ in the Nittany Valley population nearest the water gaps.

Environmental factors are not tangibly different in the two flanking valleys or adjacent to the water gaps. The uniform pattern of $f$-fixation northeast and southeast of the gaps indicates that this was probably the antecedent patten and the mixed zone east of the gaps was superimposed. It is highly probable that individuals migrating through the gaps via the Juniata River have introduced $b$ and $g$ into the eastern populations. The process may have been episodic or continuous. We envision as the most likely model a gradual site-by-site gene diffusion. Eastern populations heavily dominated by $b$ and $g$ alleles may have been initially founded by western migrants.

The pattern of Fig. 1A, headward decline of heterozygosity in an isolated drainage basin, is demonstrated by Shavers Creek Valley (Fig. 2, upper right). This valley is part of a large synclinal structure hemmed in by clastic 

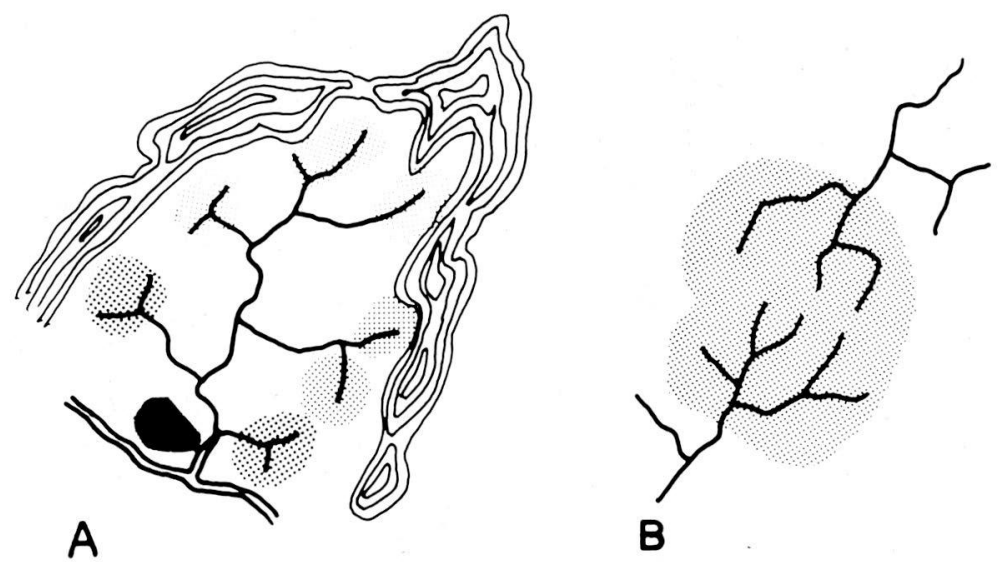

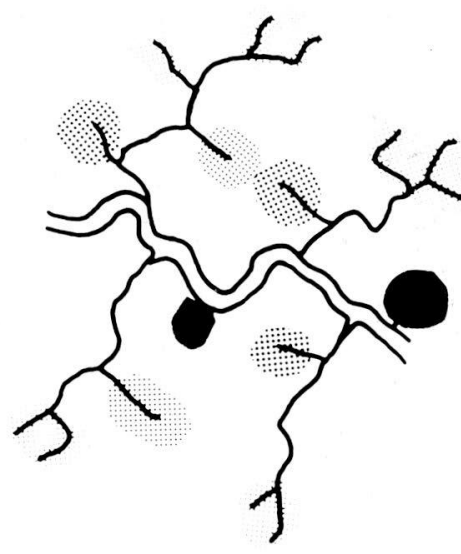

C

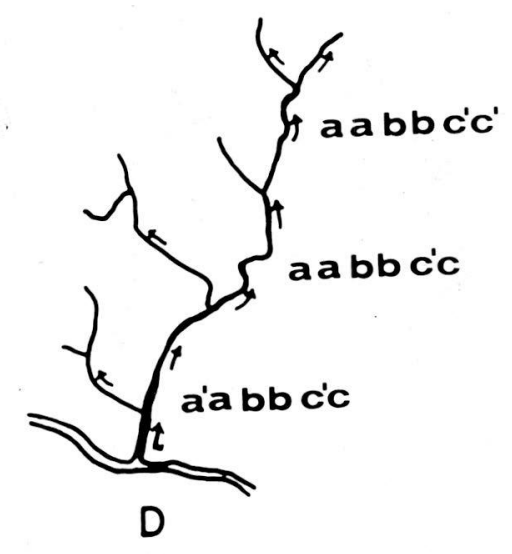

Fig. 1. Models of genetic variability in drainage basins. Heterozygosity increases with increase in stippling density.

ridges in all directions except the southwest. Average heterozygosity for three loci diminishes from 0.254 in five downstream populations to 0.074 in 10 upstream populations.

The pattern of Fig. 1B, increased heterozygosity near the divide between drainages with differentiated populations, in not found in simple form in the study area. The general concetp is demonstrated by the entire zone east of the water gaps where differentiated populations in adjacent valley drainages co- 


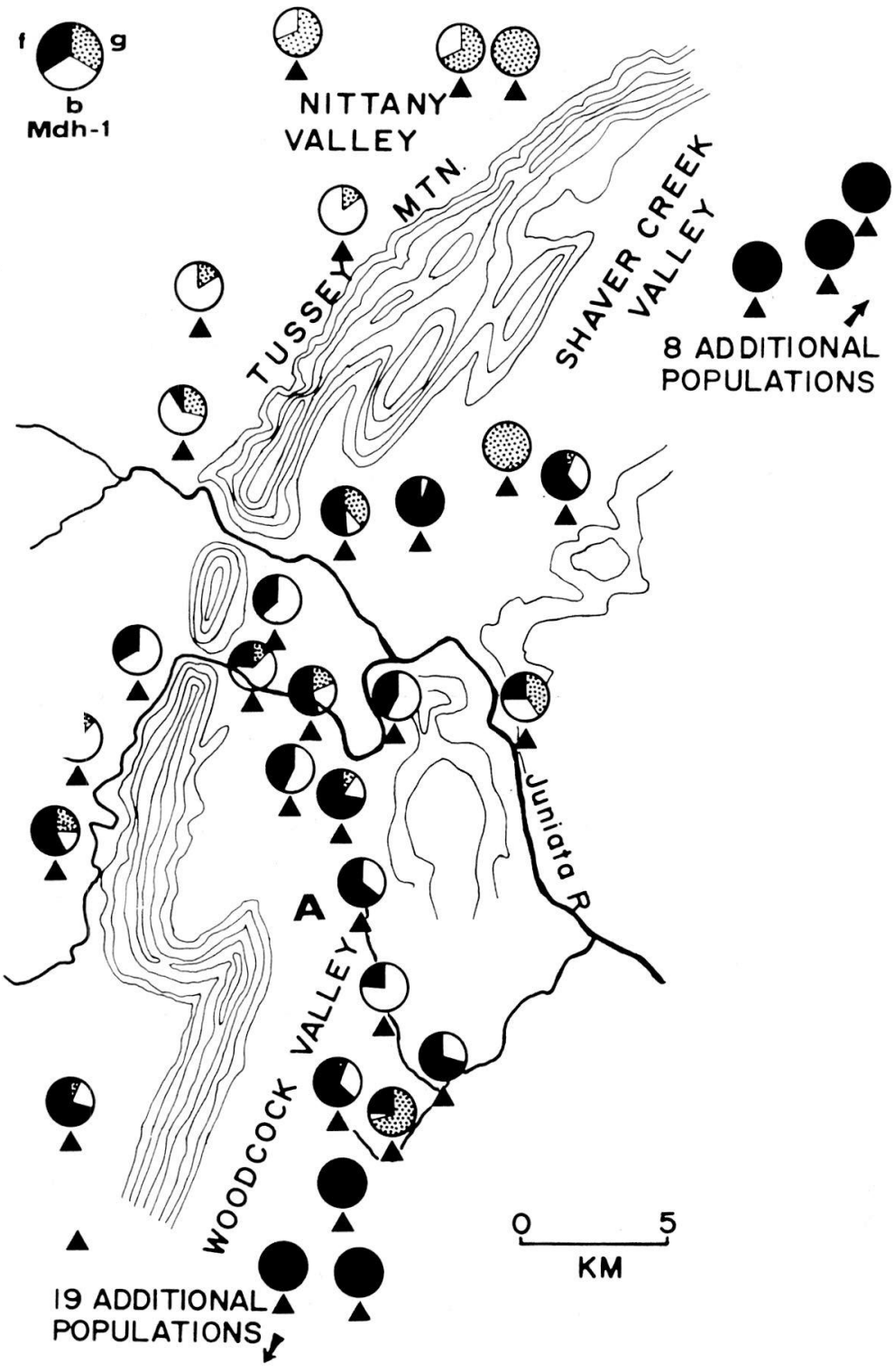

Fig. 2. Study area in central Pennsylvania. Population sites are designated by triangles, allele frequencies by sectors of circles. 
me into contact and increased heterozygosity is a consequence of gene exchange. The high heterozygosity band following the oppositely flowing streams in Woodcock Valley, near point " $A$ " of Fig. 2, also exemplifies this pattern.

Finally, the overall regional pattern is of increased heterozygosity associated with the regional master streams, as in Fig. 1C. The effect is locally amplified by the gene channelization imposed by the water gaps. It also exists, however, although less distinctly, along a long stretch of the Juniata River and its major branches distant from the water gaps.

\section{ZUSAMMENFASSUNG}

Die Genetische Struktur einer Art steht mit der Struktur der Umwelt teilweise im Einklang. Drei polymorphe Gene, welche die Enzyme Phosphoglucoseisomerase, Malate dehydrogenase und Peptidase codieren, differieren in der Genfrequenz in Abhängigkeit von der geographichen Lage bei dem Amphipoden Gammarus minus Say, der in den mittleren Appalachen (USA) vorkommt. Genetische Unterschiede treben gewöhnlich bein Stromverzweigungen und bei einer Änderung topographischer Merkmale auf. Betrachtet man unterschiedloche Allenfrequenzen Wanderungkennzeichen, so ist zu erwarten, daß die Heterozygotität in isolierten Biotopen flubaufwärts abnimmt. Dagegen nimmt sif sowohl in benachbarten, engegengesetzt fliebenden Oberläufen, in denen Genaustausch zwischen genetisch verschiedenen Populationen vorkommt, als auch im Einflußbereich naher Hauptflüsse zu. Ein derartiger genetischer Zussamenhang wurde in der Umgebung des Juniata Rivers in Zentralpennsylvanien, U.S.A., fest gestellt.

\section{LITERATURE}

ASPINWALL, N. 1974. Genetic analysis of North American populations of the pink salmon, Oncorhynchus gorbuscha, possible evidence for the neutral mutation-random drift hypothesis. Evolution 28:295-305.

COCKLEY, D.E., J.L. GOOCH, and D.P. WESTON. 1977. Genic diversity in cave-dwelling crickets (Ceuthophilus gracilipes). Evolution 31:313-318.

GOOCH, J.L., and S.W. HETRICK. 1979. The relation of genetic structure to environmental structure: Gammarus minus in a karst area. Evolution 33:192-206.

GORMAN, G.C., M. SOULE, S.Y. YANG, and E. NEVO. 1975. Evolutionary genetics of insular Adriatic lizards. Evolution 29:52-71.

JOHNSON, M.S. 1971. Adaptive lactate dehydrogenase variation in the crested blenny, Anoplarchus. Heredity 27:205-226.

KOEHN, R.K. 1969. Esterase heterogeneity: Dynamics of a polymorphism. Science 163:943944.

NEI, M. 1972. Genetic distance between populations. Am. Nat., 106:283-292.

SCHOPF, T.J.M. 1973. Survey of genetic differentiation in a coastal zone invertebrate: the ectoproct Schizoporella errata. Biol. Bull. 145:78-87. 